\title{
PRODUKSI BAWANG MERAH (Allium ascalonicum L.) DENGAN PEMBERIAN TRICHOKOMPOS TERFORMULASI DAN KALIUM DI LAHAN GAMBUT RIMBO PANJANG KABUPATEN KAMPAR, RIAU
}

\author{
Nofripa Herlina, Elsie \\ Program Studi Biologi, Fakultas MIPA dan Kesehatan \\ Universitas Muhammadiyah Riau \\ Email: nofripaherlina@umri.ac.id
}

\section{ABSTRACT}

The research aims to study the effect of the provision interaction Trichokompos of oil palm empty bunches $(O P E B)$ formulated and potassium fertilizer, the main effect of both the growth and production and K nutrient uptake by plants red onion (Allium ascalonicum L.) on peat land. The study was conducted experimentally in the form of $4 \times 3$ factorial prepared using a completely randomized design (CRD). Trichokompos OPEB formulated as the first factor consisted of 4 levels $(15,20,25$ and 30 ton / ha) and potassium as the second factor consists of three levels $\left(50,100\right.$ and $\left.150 \mathrm{~kg} \mathrm{~K} \mathrm{~K}_{2} \mathrm{O} / \mathrm{ha}\right)$. The observed parameters include the number of tillers, fresh weight of tuber per $\mathrm{m}^{2}, K$ nutrient uptake and clump of dry weight tubers per sample red onion crop. The results showed that the $25 \mathrm{ton} / \mathrm{ha}$ Trichokompos OPEB formulated and $100 \mathrm{~kg} \mathrm{~K}_{2} \mathrm{O} / \mathrm{ha}$ increased fresh weight of tuber per $m^{2}$ until 1.7 times $(71.3 \%)$, K uptake by 2.8 times (185\%) and dry weight clump of tubers per sample by 2.5 times (154.5\%) compared to the provision of 15 tons / ha at the same doses of potassium fertilizer (100 $\mathrm{kg} \mathrm{K} \mathrm{K}_{2} \mathrm{O} / \mathrm{ha}$ ). Enhancement of doses Trichokompos OPEB formulated from 15 to 25 tonnes / ha increased fresh weight of tuber per $m^{2}, K$ uptake and dry weight of tuber per sample. Enhancement of doses to 30 tonnes / ha still affect the increase in all parameters observed. Enhancement of doses potassium from 50 to 100 and $150 \mathrm{~kg} \mathrm{~K} \mathrm{O}_{2} / \mathrm{ha}$ did not affect all parameters observed.

Keywords: red onion, Trichokompos of oil palm empty bunches formulated, potash fertilizer and peat

\section{PENDAHULUAN}

Bawang merah merupakan salah satu komoditas sayuran yang mempunyai arti penting bagi masyarakat, baik dilihat dari nilai ekonomi maupun dari kandungan gizinya. Meskipun disadari bahwa bawang merah bukan merupakan kebutuhan pokok, akan tetapi kebutuhannya hampir tidak dapat dihindari oleh konsumen rumah tangga. Apabila ditinjau dari kadar gizi setiap $100 \mathrm{~g}$ daging bawang merah basah mengandung energi $38 \mathrm{kkal}$, protein 1,50 g, lemak $0,20 \mathrm{~g}$, karbohidrat $8,50 \mathrm{~g}$, kalsium 28 $\mathrm{mg}$, fosfor $41 \mathrm{~g}$, serat $0,60 \mathrm{~g}$, besi $0,90 \mathrm{mg}$, vitamin B1 0,06 mg, vitamin B2 0,04 $\mathrm{mg}$, vitamin C $8 \mathrm{mg}$, dan niasin 0,20 mg (Ditjen PHP dalam Purbiati, 2012).

Berdasarkan informasi yang diperoleh dari beberapa petani, usaha budidaya bawang merah masih belum berkembang di Riau. Sebagian petani hanya membudidayakan tanaman bawang merah dalam skala kecil, akan tetapi ketersediaannya belum mencukupi kebutuhan, sehingga untuk mencukupi kebutuhan masyarakat Riau terhadap bawang merah harus mendatangkannya dari luar Riau. Oleh karena itu, perlu dilakukan upaya pengembangan budidaya tanaman bawang merah untuk memenuhi kebutuhan masyarakat di Riau khususnya.

Riau termasuk daerah dataran rendah memiliki potensi untuk pengembangan tanaman bawang merah khususnya di lahan gambut, karena gambut di Riau cukup luas yaitu 4.360.740,2 ha (Mubekti, 2011) atau 60,08\% dari luas lahan gambut Sumatera, yaitu 6.436.649 ha (Badan Penelitian dan Pengembangan Pertanian, 2011). Namun, hingga saat ini pengembangan tanaman bawang merah di lahan gambut Riau belum banyak dilakukan.

Gambut untuk budidaya tanaman bawang merah memiliki kendala dari segi fisik dan kimia tanah. Umumnya tanah gambut memiliki kadar $\mathrm{pH}$ yang rendah, kapasitas tukar kation yang tinggi, kejenuhan basa rendah, memiliki kandungan unsur $\mathrm{K}, \mathrm{Ca}, \mathrm{Mg}$, $\mathrm{P}$ yang rendah dan 
juga memiliki kandungan unsur mikro (seperti $\mathrm{Cu}, \mathrm{Zn}, \mathrm{Mn}$ serta B) yang rendah pula. Unsur hara berperan sangat penting dalam pertumbuhan dan hasil tanaman bawang merah. Salah satu unsur hara makro utama yang diperlukan untuk pertumbuhan umbi bawang merah adalah kalium.

Kalium mempunyai fungsi yang mutlak harus ada di dalam proses metabolisme tanaman. Kalium mempunyai peran sebagai aktivator beberapa enzim dalam metabolisme tanaman, diantaranya dalam sintesis protein dan karbohidrat, serta meningkatkan translokasi fotosintat ke seluruh bagian tanaman (Nugroho, 2011). Pada bawang merah, kalium dapat memberikan hasil umbi yang lebih baik, mutu dan daya simpan umbi yang lebih tinggi dan umbi tetap padat meskipun disimpan lama (Gunadi dalam Sumarni et al., 2012).

Kebutuhan hara $\mathrm{K}$ untuk bawang merah dataran rendah yaitu $50-100 \mathrm{~kg} \mathrm{~K} \mathrm{~K}_{2} \mathrm{O} / \mathrm{ha}$ atau 100-200 kg KCl/ha (Sumarni dan Hidayat, 2005). Hasil penelitian Sitepu et al. (2011) bahwa dengan pemberian pupuk $\mathrm{KCl} 20 \mathrm{~g} / \mathrm{m}^{2}$ dihasilkan diameter umbi terbesar, bobot basah umbi per sampel dan bobot umbi kering per sampel terberat yaitu masing-masing sebesar $3,72 \mathrm{~cm}, 18,69 \mathrm{~g}$ dan 5,61 g secara berurutan, namun pemberian unsur $\mathrm{K}$ saja belum cukup memenuhi kebutuhan tanaman bawang merah untuk tumbuh dan produksi lebih optimal, maka perlu penambahan bahan organik ke dalam tanah.

Salah satu bahan organik yang diberikan adalah tandan kosong kelapa sawit (tankos) yang telah dikomposkan dengan menggunakan Trichoderma sp. sebagai dekomposer yang diperkaya dengan zeolit dan tepung tapioka yang disebut dengan Trichokompos tandan kosong kelapa sawit terformulasi atau Trichokompos TKKS terformulasi. Hasil penelitian Ichwan (2007) bahwa pemberian Trichokompos dengan berbagai dosis memberikan pengaruh yang nyata terhadap pertumbuhan dan hasil tanaman cabe merah.

Berdasarkan uraian di atas, maka pemberian Trichokompos terformulasi dan pupuk $\mathrm{K}$ dalam rangka meningkatkan kesuburan tanah di lahan gambut untuk menunjang pertumbuhan dan perkembangan umbi bawang merah sangatlah diperlukan, namun dosis Trichokompos terformulasi dan pupuk $\mathrm{K}$ yang tepat bagi tanaman bawang merah belum diketahui khususnya lahan gambut di Riau. Oleh sebab itu, melalui penelitian ini diharapkan mendapatkan dosis Trichokompos dan pupuk kalium yang tepat yang akhirnya dapat menghasilkan pertumbuhan, produksi dan kualitas umbi bawang merah yang lebih baik dan optimal di lahan gambut.

Penelitian ini bertujuan untuk mengetahui pengaruh utama Trichokompos terformulasi dan pengaruh utama kalium serta interaksi keduanya terhadap produksi umbi bawang merah (Allium ascalonicum L.) di lahan gambut.

\section{METODOLOGI PENELITIAN}

Penelitian dilakukan secara eksperimen yang disusun secara faktorial menggunakan Rancangan Acak Lengkap (RAL) yang terdiri dari 2 faktor.

Faktor I adalah Trichokompos terformulasi dengan 4 taraf, yaitu:

$\mathrm{T} 1 \quad$ : 2,3 kg/ plot Trichokompos terformulasi (15 ton/ ha)

T2 : $3 \mathrm{~kg} /$ plot Trichokompos terformulasi (20 ton/ ha)

T3 : 3,8 kg/ plot Trichokompos terformulasi ( 25 ton/ ha)

T4 : 4,5 kg/ plot Trichokompos terformulasi (30 ton/ ha)

Faktor II adalah pupuk kalium dengan 3 taraf, yaitu:

$\mathrm{K} 1: 50 \mathrm{~kg} \mathrm{~K}_{2} \mathrm{O} / \mathrm{ha}$

$\mathrm{K} 2: 100 \mathrm{~kg} \mathrm{~K}_{2} \mathrm{O} / \mathrm{ha}$

$\mathrm{K} 3: 150 \mathrm{~kg} \mathrm{~K}_{2} \mathrm{O} / \mathrm{ha}$

Dua faktor di atas menghasilkan kombinasi perlakuan sebanyak 4 x $3=12$ kombinasi dengan 3 ulangan menjadi 36 satuan percobaan.

Data penelitian yang diperoleh dianalisis secara statistik dengan menggunakan analisis ragam. Jika hasil sidik ragam 
berpengaruh nyata akan di uji lanjut dengan menggunakan Duncan New Multiple Range Test (DNMRT) pada taraf 5\%. Parameter yang diamati adalah jumlah anakan, bobot segar umbi per $\mathrm{m}^{2}$, serapan hara $\mathrm{K}$ dan bobot kering umbi per sampel.

\section{HASIL DAN PEMBAHASAN}

\subsection{Jumlah Anakan per Rumpun Sampel}

Hasil sidik ragam menunjukkan bahwa pemberian Trichokompos TKKS terformulasi, pupuk kalium dan interaksi keduanya berpengaruh tidak nyata terhadap jumlah anakan tanaman bawang merah. Hasil uji lanjut dengan DNMRT taraf 5\% disajikan pada Tabel 1 .

Tabel 1.

Jumlah anakan bawang merah (batang) umur 45 HST pada lahan gambut dengan pemberian Trichokompos TKKS terformulasi dan pupuk kalium

\begin{tabular}{cccc}
\hline Trichokompos & \multicolumn{3}{l}{ Pupuk Kalium $\left(\mathrm{kg} \mathrm{K}_{2} \mathrm{O} / \mathrm{ha}\right)$} \\
\cline { 2 - 4 } $\begin{array}{c}\text { TKKS } \\
\text { terformulasi } \\
\text { (ton/ha) }\end{array}$ & 50 & 100 & 150 \\
\hline 15 & 7,89 & 8,66 & 8,11 \\
20 & 8,99 & 7,89 & 7,44 \\
25 & 7,89 & 10,00 & 7,66 \\
30 & 8,66 & 8,77 & 9,33 \\
\hline
\end{tabular}

Tabel 1 menunjukkan bahwa pemberian Trichokompos TKKS terformulasi dan pupuk kalium tidak terjadi interaksi secara nyata terhadap jumlah anakan bawang merah, namun pemberian Trichokompos TKKS terformulasi 25 ton/ha dan pupuk kalium $100 \mathrm{~kg} \mathrm{~K}_{2} \mathrm{O}$ /ha cenderung menghasilkan jumlah anakan tertinggi atau meningkat sebesar $34,41 \%$ dibandingkan dengan pemberian Trichokompos TKKS terformulasi 20 ton/ha dan pupuk kalium $150 \mathrm{~kg} \mathrm{~K}_{2} \mathrm{O} / \mathrm{ha}$. Tidak terjadinya interaksi diduga terjadi kehilangan unsur hara karena tercuci oleh curah hujan yang relatif tinggi di awal penelitian, serta kurangnya intensitas matahari juga mengakibatkan terganggunya proses fotosintesis yang akan berpengaruh langsung terhadap pertumbuhan dan perkembangan jumlah anakan tanaman bawang merah.
Hasil penelitian Purbiati, et al. (2010) tentang uji varietas bawang merah di lahan gambut dataran rendah Kabupaten Kuburaya Kalimantan Barat bahwa varietas Bauji berumur 30 HST menghasilkan jumlah anakan rata-rata 5,29 batang. Hidayat, et al. (2011) melaporkan bahwa varietas Bauji yang ditanam di Brebes menghasilkan jumlah anakan rata-rata 8,07, di Tegal 6,33 dan di Nganjuk 6,93.

Beberapa hasil penelitian menunjukkan bahwa pemupukan tidak meningkatkan jumlah anakan bawang merah per tanaman secara nyata. Jumlah anakan bawang merah lebih banyak ditentukan oleh faktor genetik selain faktor lingkungan daripada faktor pemupukan (Sumarni, et al., 2012; Koheri, et al., 2015; Firmansyah, et al., 2014).

\subsection{Bobot Segar Umbi per $\mathbf{m}^{2}$}

Hasil sidik ragam menunjukkan bahwa pemberian Trichokompos TKKS terformulasi berpengaruh nyata terhadap bobot segar umbi per $\mathrm{m}^{2}$, sedangkan pemberian pupuk kalium dan interaksi keduanya berpengaruh tidak nyata terhadap bobot segar umbi per $\mathrm{m}^{2}$. Hasil uji lanjut dengan DNMRT taraf $5 \%$ disajikan pada Tabel 2.

\section{Tabel 2.}

Bobot segar umbi $\left(\mathrm{g} / \mathrm{m}^{2}\right)$ dengan perlakuan Trichokompos TKKS terformulasi dan pupuk kalium di lahan gambut

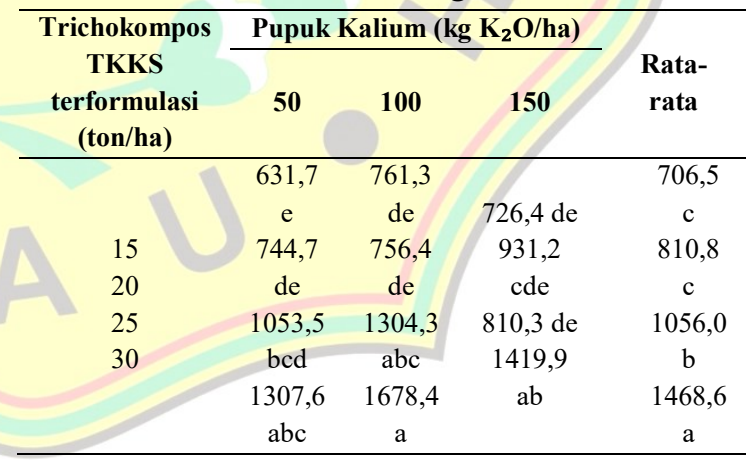

Angka-angka yang diikuti oleh huruf kecil pada kolom dan baris yang sama berbeda tidak nyata menurut uji Duncan pada taraf 5\%

Tabel 2 menunjukkan bahwa pemberian Trichokompos TKKS terformulasi 25 ton/ha dan pupuk kalium $100 \quad \mathrm{~kg} \quad \mathrm{~K}_{2} \mathrm{O} / \mathrm{ha}$ meningkatkan bobot segar umbi per $\mathrm{m}^{2}$ sebesar 
1,7 kali (71,3\%) dibandingkan dengan pemberian 15 ton/ha pada dosis pupuk kalium yang sama ( $\left.100 \mathrm{~kg} \mathrm{~K}_{2} \mathrm{O} / \mathrm{ha}\right)$. Hal ini disebabkan semakin tinggi dosis yang diberikan, baik dari Trichokompos TKKS terformulasi maupun dari pupuk kalium, tentu semakin tinggi pula ketersediaan unsur hara di dalam tanah terutama hara K. Semakin tinggi ketersediaan hara K, semakin tinggi pula serapan $\mathrm{K}$ oleh akar tanaman yang akan memberikan kontribusi terhadap peningkatan bobot segar umbi. Apabila dikonversi ke hektar $\left(10.000 \quad \mathrm{~m}^{2}\right)$ diperoleh bobot segar umbi per meter persegi sekitar 13 ton/ha.

Tabel 2 juga menunjukkan bahwa peningkatan dosis Trichokompos TKKS terformulasi hingga 25 ton/ha meningkatkan bobot segar umbi per $\mathrm{m}^{2}$ sebesar 1,49 kali (49,5\%) dibandingkan dengan pemberian 15 ton/ha. Hal ini disebabkan semakin tinggi dosis Trichokompos TKKS terformulasi yang diberikan tentu semakin tinggi pula ketersediaan unsur hara di dalam tanah yang akan memberikan kontribusi terhadap peningkatan bobot segar umbi.

Adanya kandungan hara makro dalam Trichokompos TKKS terformulasi khususnya $\mathrm{K}$ mempengaruhi proses fotosintesis dan translokasi hasil fotosintesis ke seluruh bagian tanaman terutama dalam pembentukan umbi, karena $\mathrm{K}$ berperan dalam translokasi karbohidrat. Karbohidrat yang ditranslokasi di metabolisme menjadi berbagai senyawa penyusun jaringan/ organ tanaman, khususnya dalam penambahan bobot segar umbi.

Sjofjan dan Idwar (2009) menyatakan bahwa ketersediaan hara $\mathrm{K}$ tanah meningkatkan konsentrasi $\mathrm{K}^{+}$pada daun dan pengaruhnya pada proses membukanya stomata, penambatan $\mathrm{CO}_{2}$ dan proses fotosintesis. Hasilnya berupa fotosintat dibutuhkan tanaman untuk menghasilkan energi yang dibutuhkan dalam pertumbuhan dan pembelahan sel-sel meristematis, yang menghasilkan pertambahan berat dan ukuran organ-organ tanaman.

Bahan organik yang berasal dari Trichokompos TKKS terformulasi dapat meningkatkan bobot segar umbi dengan cara memperbaiki sifat fisik tanah yaitu meningkatkan pori-pori tanah, memperbaiki tata udara dan air tanah, sehingga sistem perakaran menjadi lebih baik. Kondisi demikian akan meningkatkan serapan hara oleh akar tanaman yang akhirnya mempengaruhi bobot segar umbi bawang merah. Selain itu, bahan organik juga dapat memperbaiki sifat kimia tanah dengan cara meningkatkan $\mathrm{pH}$ tanah. Menurut Hardjowigeno dalam Sari (2011) bahwa $\mathrm{pH}$ tanah menentukan mudah tidaknya unsur-unsur hara baik makro maupun mikro diserap oleh akar tanaman.

Fotosintesis dan metabolisme tanaman tidak hanya dipengaruhi oleh jumlah dan keseimbangan hara, tetapi juga oleh ketersediaan air. Ketersediaan air yang cukup dipengaruhi oleh pemberian bahan organik. Bahan organik yang berasal dari Trichokompos TKKS terformulasi dapat meningkatkan poripori tanah, memperbaiki tata udara dan air tanah, sehingga menyebabkan kebutuhan tanaman bawang merah terhadap air tercukupi dan akar lebih banyak menyerap unsur hara, sehingga fotosintesis meningkat dan asimilat dapat ditranslokasikan ke seluruh bagian tanaman terutama umbi.

Hasil penelitian Sitepu, et al. (2011) menunjukkan bahwa dengan pemberian $200 \mathrm{~kg}$ $\mathrm{KCl}$ /ha dihasilkan bobot basah umbi bawang merah per sampel dan bobot kering umbi per sampel terberat yaitu masing-masing sebesar $18,69 \mathrm{~g}$ dan $5,61 \mathrm{~g}$ secara berurutan.

\subsection{Serapan Hara K}

Kandungan dan serapan hara $\mathrm{K}$ oleh umbi dan daun tanaman bawang merah di lahan gambut disajikan pada Tabel 3 . 
Tabel 3.

Kandungan (\%) dan serapan hara $\mathrm{K}$ (g/ rumpun) oleh umbi dan daun bawang merah di lahan gambut dengan pemberian Trichokompos TKKS terformulasi dan pupuk kalium

\begin{tabular}{|c|c|c|c|c|}
\hline \multicolumn{2}{|c|}{ Kombinasi perlakuan } & \multirow{3}{*}{$\begin{array}{c}\text { Kandungan } \\
\text { Hara K } \\
(\%)\end{array}$} & \multirow{2}{*}{\multicolumn{2}{|c|}{ Serapan Hara K }} \\
\hline Trichokompos & & & & \\
\hline $\begin{array}{l}\text { TKKS Terformulasi } \\
\text { (ton/ha) }\end{array}$ & $\begin{array}{l}\text { Pupuk Kalium } \\
\left(\mathrm{kg} \mathrm{K}_{2} \mathrm{O} / \mathrm{ha}\right)\end{array}$ & & $\begin{array}{c}\text { Nilai } \\
\text { (g/rumpun) }\end{array}$ & $\begin{array}{l}\text { Rata-rata } \\
\text { (g/rumpun) }\end{array}$ \\
\hline 15 & 50 & 2 & 14,82 & \\
\hline 15 & 100 & 2,39 & 23,37 & 16,83 \\
\hline 15 & 150 & 2,13 & 12,29 & \\
\hline 20 & 50 & 1,84 & 16,44 & \\
\hline 20 & 100 & 2,23 & 28,81 & 28,56 \\
\hline 20 & 150 & 2,01 & 40,44 & \\
\hline 25 & 50 & 1,99 & 53,92 & \\
\hline 25 & 100 & 2,72 & 64,7 & 48,09 \\
\hline 25 & 150 & 1,9 & 25,65 & \\
\hline 30 & 50 & 1,83 & 43,51 & \\
\hline $\begin{array}{l}30 \\
30\end{array}$ & 100 & 1,9 & 54,83 & 53,94 \\
\hline 30 & 150 & 1,86 & 63,5 & \\
\hline
\end{tabular}

Tabel 3 menunjukkan bahwa pemberian Trichokompos TKKS terformulasi 25 ton/ha meningkatkan nilai serapan hara $\mathrm{K}$ sebesar 2,8 kali (185\%) dibandingkan dengan pemberian 15 ton/ha. Hal ini disebabkan peningkatan dosis Trichokompos TKKS terformulasi tentu diikuti oleh peningkatan ketersediaan unsur hara, khususnya hara $\mathrm{K}$ sehingga dapat diserap oleh akar tanaman. Trichokompos TKKS terformulasi mengandung mikroba sebagai dekomposer dan zeolit sebagai bahan pembenah tanah yang bekerja secara sinergis dalam merombak bahan organik yang ada dalam medium tanah, sehingga hasil dari perombakan tersebut menyumbangkan unsur hara salah satunya unsur kalium. Tersedianya unsur kalium yang berasal dari dekomposisi bahan organik tersebut, maka semakin banyak unsur kalium yang diserap oleh tanaman. Sumarni, et al. (2012) melaporkan bahwa pemberian pupuk kalium dosis $120 \quad \mathrm{~kg} \quad \mathrm{~K}_{2} \mathrm{O} / \mathrm{ha}$ dapat meningkatkan serapan hara $\mathrm{K}$ tanaman bawang merah. Syakir dan Gusmaini (2012) juga melaporkan bahwa serapan $\mathrm{K}$ tertinggi untuk produksi minyak tanaman nilam yaitu pada pemberian $120 \mathrm{~kg} \mathrm{KCl} / \mathrm{ha}$.

Secara umum, kombinasi antara perlakuan aplikasi berbagai dosis Trichokompos TKKS terformulasi dengan pupuk kalium memperlihatkan bahwa Trichokompos TKKS terformulasi 25 ton/ha menunjukkan hasil yang berpengaruh nyata dalam hal pertumbuhan generatif tanaman bawang merah. Hal ini disebabkan faktor utama aplikasi Trichokompos TKKS terformulasi lebih dominan terlihat pengaruhnya terhadap seluruh parameter yang diamati, karena Trichokompos TKKS terformulasi memiliki komposisi hara makro lengkap dengan komposisi 2,10\% $\mathrm{N}$, $2,16 \% \quad \mathrm{P}_{2} \mathrm{O}_{5}, 2,49 \% \quad \mathrm{~K}_{2} \mathrm{O}, 0,55 \% \mathrm{MgO}$ dan $0,99 \% \mathrm{CaO}$, serta memiliki kandungan mikroorganisme yang dapat mendekomposisi bahan organik menjadi bentuk-bentuk yang tersedia bagi tanaman, sehingga tanaman bawang merah tumbuh dan menyerap unsur hara lebih baik.

\subsection{Bobot Kering Umbi per Rumpun sampel}

Hasil sidik ragam menunjukkan bahwa pemberian Trichokompos TKKS terformulasi dan interaksi dengan pupuk kalium berpengaruh nyata terhadap bobot kering umbi bawang merah per sampel, sedangkan pemberian pupuk kalium berpengaruh tidak nyata terhadap bobot kering umbi bawang merah per sampel. Hasil uji lanjut dengan DNMRT taraf $5 \%$ disajikan pada Tabel 4.

Tabel 4 menunjukkan bahwa pemberian Trichokompos TKKS terformulasi 25 ton/ha 
dan pupuk kalium $100 \quad \mathrm{~kg} \quad \mathrm{~K}_{2} \mathrm{O} / \mathrm{ha}$ meningkatkan bobot kering umbi per sampel sebesar 2,5 kali (154,5\%) dibandingkan dengan pemberian 15 ton/ha pada dosis pupuk kalium yang sama (100 $\left.\mathrm{kg} \quad \mathrm{K}_{2} \mathrm{O} / \mathrm{ha}\right)$. Tetapi, peningkatan dosis Trichokompos TKKS terformulasi hingga 30 ton/ha tidak begitu besar pengaruhnya terhadap parameter tersebut pada setiap dosis pupuk kalium. Hal ini disebabkan interaksi antara Trichokompos TKKS terformulasi 25 ton/ha dan pupuk kalium $100 \mathrm{~kg}$ $\mathrm{K}_{2} \mathrm{O} /$ ha memberikan unsur hara yang cukup dan seimbang untuk pertumbuhan generatif bawang merah.

Tabel 4.

Bobot kering umbi per sampel (g/rumpun) dengan perlakuan Trichokompos TKKS terformulasi dan pupuk kalium di lahan gambut

\begin{tabular}{ccccc}
\hline $\begin{array}{c}\text { Trichokompos TKKS } \\
\text { terformulasi }\end{array}$ & \multicolumn{3}{c}{ Pupuk Kalium $\left(\mathrm{kg} \mathrm{K}_{2} \mathrm{O} / \mathrm{ha}\right)$} & \\
\cline { 2 - 4 } (ton/ha) & 50 & 100 & 150 & Rata-rata \\
\hline 15 & $6,62 \mathrm{~d}$ & $8,82 \mathrm{~d}$ & $5,25 \mathrm{~d}$ & $6,89 \mathrm{~d}$ \\
20 & $8,29 \mathrm{~d}$ & $12,18 \mathrm{~cd}$ & $19,19 \mathrm{bc}$ & $13,22 \mathrm{c}$ \\
25 & $26,07 \mathrm{ab}$ & $22,45 \mathrm{~b}$ & $12,62 \mathrm{~cd}$ & $20,38 \mathrm{~b}$ \\
30 & $22,30 \mathrm{~b}$ & $27,31 \mathrm{ab}$ & $32,74 \mathrm{a}$ & $27,45 \mathrm{a}$ \\
\hline
\end{tabular}

Angka-angka yang diikuti oleh huruf kecil pada kolom dan baris yang sama berbeda tidak nyata menurut uji Duncan pada taraf 5\%

Tabel 4 juga menunjukkan bahwa peningkatan dosis Trichokompos TKKS terformulasi hingga 25 ton/ha meningkatkan bobot kering umbi per sampel sebesar 2,95 kali (195,8\%) dibandingkan dengan pemberian 15 ton/ha. Hal ini disebabkan peningkatan dosis Trichokompos TKKS terformulasi tentu diikuti oleh peningkatan ketersediaan unsur hara makro maupun unsur hara mikro di dalam tanah, terutama hara $\mathrm{K}$. Mengingat unsur hara $\mathrm{K}$ sangat dibutuhkan tanaman pada proses pembentukan dan pembesaran umbi. Menurut Anisyah, et al. (2014) pembentukan umbi bawang merah berasal dari pembesaran lapisan-lapisan daun yang kemudian berkembang menjadi umbi bawang merah. Kandungan $\mathrm{K}$ yang tinggi menyebabkan ion $\mathrm{K}^{+}$yang mengikat air dalam tubuh tanaman akan mempercepat proses fotosintesis. Hasil fotosintesis inilah yang merangsang pembentukan umbi menjadi lebih besar sehingga dapat meningkatkan bobot kering tanaman.
Ketersediaan unsur hara nitrogen, fosfor, kalium dan magnesium yang optimal bagi tanaman dapat meningkatkan pembentukan klorofil. Peningkatan klorofil akan meningkatkan aktifitas fotosintesis, sehingga menghasilkan fotosintat yang lebih banyak yang akan mendukung berat kering tanaman. Hal ini dibuktikan pada tabel korelasi yang memperlihatkan bahwa nilai bobot kering umbi berkorelasi erat dengan parameter serapan hara $\mathrm{K}$ dengan rerata koefisien korelasi mencapai $0,95 \%$. Hal ini mengindikasikan bahwa baiknya sistem perakaran dalam menyerap unsur hara. Silaban, et al. (2014) menyatakan bahwa berat kering tanaman mencerminkan status nutrisi, dan berat kering tanaman merupakan indikator baik atau tidak baiknya suatu tanaman dan sangat erat kaitannya dengan ketersediaan hara.

Selain itu, peningkatan $\mathrm{pH}$ tanah gambut dari 5,1-5,6 (Tabel 2) juga memberikan kontribusi terhadap ketersediaan unsur hara yang dapat diserap oleh tanaman. Hasil penelitian Refliaty, et 
al. (2013) menunjukkan bahwa pemberian Trichokompos dapat memperbaiki sifat kimia tanah (meningkatkan $\mathrm{pH}$ dan KTK tanah Ultisol), meningkatkan pertumbuhan tanaman dan bobot kering biji kedelai.

\section{KESIMPULAN DAN SARAN}

\subsection{Kesimpulan}

Berdasarkan hasil penelitian, maka dapat disimpulkan beberapa hal sebagai berikut:

1. Pemberian 25 ton/ha Trichokompos TKKS terformulasi dan $100 \mathrm{~kg} \mathrm{~K}_{2} \mathrm{O} / \mathrm{ha}$ meningkatkan bobot segar umbi per $\mathrm{m}^{2}$ hingga 1,7 kali $(71,3 \%)$, serapan $\mathrm{K}$ sebesar 2,8 kali (185\%) dan bobot kering umbi per rumpun sampel sebesar 2,5 kali $(154,5 \%)$ dibandingkan pemberian 15 ton/ha Trichokompos TKKS terformulasi pada dosis pupuk kalium yang sama ( $\left.100 \mathrm{~kg} \mathrm{~K}_{2} \mathrm{O} / \mathrm{ha}\right)$.

2. Peningkatan dosis Trichokompos TKKS terformulasi dari $15 \mathrm{ke} 25$ ton/ha meningkatkan bobot segar umbi per $\mathrm{m}^{2}$, serapan hara $\mathrm{K}$ dan bobot kering umbi per rumpun sampel. Peningkatan dosis ke 30 ton/ha masih berpengaruh terhadap peningkatan seluruh parameter yang diamati.

Peningkatan dosis pupuk kalium dari 50 ke 100 hingga $150 \mathrm{~kg} \mathrm{~K}_{2} \mathrm{O} /$ ha tidak mempengaruhi seluruh parameter yang diamati.

\subsection{Saran}

Untuk mendukung produksi tanaman bawang merah yang optimal di lahan gambut disarankan untuk menggunakan Trichokompos TKKS terformulasi dosis 25 ton/ha dan pupuk kalium $100 \mathrm{~kg} \mathrm{~K}_{2} \mathrm{O} / \mathrm{ha}$.

\section{DAFTAR PUSTAKA}

Badan Penelitian dan Pengembangan Pertanian. 2011. Peta Lahan Gambut Indonesia. http://bbsdlp.litbang.deptan.go.id.

Akses tgl 09 September 2014.

Balai Penelitian Tanaman Sayuran. 2013. Budidaya Bawang Merah. Balitsa.litbang.deptan.go.id. Tanggal akses: 11 Agustus 2014.
Gunadi. 2009. Kalium Sulfat dan Kalium Klorida Sebagai Sumber Pupuk Kalium Pada Tanaman Bawang Merah. J.Hort (19)2, 174-185.

Heyde J, Noor YR. 2007. Pengelolaan Lahan Gambut Berbasis Masyarakat di Indonesia. Wetlands International, Indonesia Programme, Bogor.

Ichwan B. 2007. Pengaruh Dosis Trichokompos Terhadap Pertumbuhan dan Hasil Tanaman Cabe Merah. Jurnal Agronomi, Vol.11 No. 1 Hal.47-50.

Irfan M. 2013, Respon Bawang Merah (Allium ascalonicum L.) Terhadap Zat Pengatur Tumbuh dan Unsur Hara. Jurnal Agroteknologi. Vol. 3. No. 2, Hal. 35 40.

Mubekti, 2011. Studi Pewilayahan Dalam Rangka Pengelolaan Lahan Gambut Berkelanjutan di Propinsi Riau. Jurnal Sains dan Teknologi Indonesia. Vol 13 No 2. Hal: 88-94

Najiyati S., Lili Muslihat dan I Nyoman N. Suryadiputra. 2005. Panduan Pengelolaan Lahan Gambut Untuk Pertanian Berkelanjutan. ProyekClimate Change, Forests and Peatlands in Indonesia. Wetlands International - Indonesia Programme dan Wildlife Habitat Canada. Bogor.

Napitupulu D dan Winarto L. 2010. Pengaruh Pemberian Pupuk N dan K Terhadap Pertumbuhan dan Produksi Bawang Merah. J-Hort. 20(1): 27-35

Nugroho. 2011, Peran Konsentrasi Pupuk Daun dan Dosis Pupuk Kalium Terhadap Hasil Tanaman Tomat (Lycopersicum esculentum Mill.). Politeknosains Edisi Khusus Dies Natali. Fakultas Pertanian Universitas Boyolali.

PT. Sarana Inti Pratama, 2014. Kandungan Unsur Hara Tricho-kompos. Pekanbaru. (Analisis tgl 6 Februari 2014).

Purbiati T. 2012. Potensi Pengembangan Bawang Merah di Lahan Gambut. $J$. Litbang Pert. Vol 31 No 3. Hal: 113118 
Ratmini NPS. 2012. Karakteristik dan Pengelolaan Lahan Gambut Untuk Pengembangan Pertanian. Jurnal Lahan Suboptimal. Vol. 1, No. 2 Hal: 197-206.

Sasli I. 2011. Karakterisasi Gambut Dengan Berbagai Bahan Amelioran dan Pengaruhnya Terhadap Sifat Fisik dan Kimia Guna Mendukung Produktivitas Lahan Gambut. Agrovigor. Vol. 4, No. 1, Hal. 42-50.

Sitepu BH, Ginting S, Mariati. 2011. Respon Pertumbuhan dan Produksi Bawang Merah (Allium ascalonicum L. Var. Tuktuk) Asal Biji Terhadap Pemberian Pupuk Kalium dan Jarak Tanam. Jurnal Online Agroekoteknologi Vol.1, No.3. Sumanto, Syakir, Allorerung D, Purwani J.
2011. Kompos Kulit Jarak Pagar Sebagai Sumber Kalium Potensial. Prosiding Seminar Nasional Inovasi Perkebunan.

Sumarni N, Hidayat A. 2005. Budidaya Bawang Merah, Panduan Teknis PTT Bawang Merah No. 3. Balai Penelitian Tanaman Sayuran.

Sumarni N, Rosliani R, Basuki RS, Hilman Y. 2012. Pengaruh Varietas, Status KTanah, Dosis Pupuk Kalium Terhadap Pertumbuhan, Hasil Umbi dan Serapan Hara K Tanaman Bawang Merah. $J$. Hort. 22(3):233-241.

Umar. 2013. Respon Bawang Merah Varietas Mentes Terhadap Pupuk NPK Majemuk di Dataran Tinggi Lembang. Seminar Nasional. 